\title{
INTERNATIONAL ECONOMIC STANDARDS OF MEDICAL PROVISION: LEGAL CHARACTERISTICS AND PROBLEMS OF IMPLEMENTATION IN UKRAINE
}

\author{
Dmytro Bilinskyi ${ }^{1}$, Mushfik Damirchyiev²
}

\begin{abstract}
The purpose of the paper is to analyze the current legislation on medical reform in the context of harmonization with international standards. In the conditions of social state building in Ukraine, the thesis is axiomatic regarding that the state should show concern for their citizens, including for the protection of their health. In this context, it is relevant to study the implementation of medical reform in Ukraine, since its content and the degree to which the proclaimed provisions are enforced depend on the ability of each person to access quality health care. Methodology. The article is based on international legal acts, laws and by-laws of Ukraine in the field of legal regulation of medical care. Both general scientific and special methodology were used for the research. Methods of analysis and synthesis, method of description, method of induction, method of deduction, method of correlation, etc. were applied. Results. The article defines the directions for harmonization of the legislation of Ukraine on health protection in accordance with international standards. Based on the ECHR practice, proposals have been formulated to improve the legislation of Ukraine. Conclusions. The ECHR has repeatedly concluded that the right to health is complex and includes: the right to information about one's health and the confidentiality of such information; the right to health care; the right to choose the doctor and the remedies freely; the right to a safe environment that affects health and so on. The state does not cover all aspects of providing medical care to citizens, but resorts to limited funding, since the state budget funds are only one of the types of sources of financing. Practical implications. We have formulated the following tasks: to analyze Ukraine's international legal obligations regarding health care; to identify major changes in health care financing and health care delivery in line with health care reform standards in Ukraine; to identify major health care funding issues.
\end{abstract}

Key words: health and economic development, international law, government expenditures and health.

JEL Classification: H51, 115, K33

\section{Introduction}

It is the duty of the State to provide medical assistance to all those in need as it is enshrined in the International Covenant on Economic Social and Cultural Rights (Article 12, International Covenant on Economic, Social and Cultural Rights, 1976), the Universal Declaration of Human Rights (Article 25, Universal Declaration of Human Rights, 1948); The State's obligation to provide children with the highest quality medical care as enshrined in the UN Convention on the Rights of the Child (Article 24, Convention on the Rights of the Child, 1989); The obligation to provide health care to protected persons within the limits necessary to restore normal health is provided for in the European Code of

Corresponding author:

${ }^{1}$ Yaroslav Mudryi National Law University, Ukraine.

E-mail: dmytro.bilinskyi@gmail.com

ORCID: https://orcid.org/0000-0001-5694-9352

ResearcherID: F-6099-2019

${ }^{2}$ Yaroslav Mudryi National Law University, Ukraine.

E-mail: m.damirchiev@gmail.com

ORCID: https://orcid.org/0000-0002-9734-7988

ResearcherID: F-7030-2019
Social Security (Articles 7-12, European Social Charter, 1996) and the European Social Charter (Article 11, European Social Charter, 1996).

In order to cover the topics chosen, one should focus on the case law of the European Court of Human Rights in the context of ensuring the right to life and health. The European Convention for the Protection of Human Rights and Fundamental Freedoms of 1950 provided for a mechanism for the protection and enjoyment of entrenched rights and freedoms through an application to the European Court of Human Rights (hereinafter referred to as ECHR) (Convention for the Protection of Human Rights and Fundamental Freedoms,1950). The protection of the right to health directly by the 
1950 Convention, like other socio-economic rights, is not envisaged, but the protection of this right is possible in accordance with the protection of the right to life.

Prior to opening the city of individual ECHR Decisions, emphasis should be placed. First, the ECHR has not developed a large body of case law on the protection of medical human rights. This is because the ECHR interprets the issue of medicine not on its own but in the context of the universal right to life. Second, the ECHR does not give human health a separate interpretation in isolation from the life of the individual and the environment in which he/she lives. Third, the ECHR makes individual interpretations and clarifications in each case, which we will outline below.

\section{The right to health is complex}

The ECHR has repeatedly concluded that the right to health is complex and includes: the right to information about one's health and the confidentiality of such information; the right to health care; the right to choose the doctor and the remedies freely; the right to a safe environment that affects health and so on. The realization of the right to life is not possible without the exercise of the right to health which the ECHR interprets as an indispensable part of the right to life.

The right to life is protected in Art. 2 of the Convention. Violation of this right is also a cause of harm to health, even if such damage did not cause his/her death, but posed a serious threat to his/her life (Senyuta, I, 2015). The positive obligation of the state is the protection of human life and the existence of an effective independent forensic system, which allows to determine the death causes, if it occurred at the hospital or if the patient was under constant and effective medical control, and the degree of responsibility of medical staff.

Art. 2 of the Convention provides for minimum procedural requirements whereby in cases where the state or its representatives are potentially liable for the death of a person, the suspected circumstances should be the subject of effective investigation or thorough examination to bring the facts to the public attention (End of life and the European Convention on Human Rights). The ECHR has taken the position that cases concerning the deaths of patients in healthcare facilities should be resolved as quickly as possible. The case of Byrzhykowski v. Poland, where the Court emphasized the need for a speedy resolution of cases concerning the death of a person in medical institutions, is of prime importance for disclosing the content of this legal position.

Mistakes made during health and medical care provision must be resolved quickly. Further, this information should be immediately disseminated to the ECHR, indicating that we need to comply with the standards of Article 2 of the Convention as regards the development of experience and medical practice in order to reduce patient mortality.
Considering the Convention for the Protection of Human Rights and Fundamental Freedoms as a source of medical law, it should be kept in mind that it is not intended to provide material guarantees for state medical guarantees (Boyle, 2004). That is, a state's failure to comply with national health standards does not justify applying to the ECHR. It is possible to understand the ECHR's legal approaches in this area when examining its decision in the case of Popov v. The Russian Federation dated 13 July 2006, where the Court noted that under Art. 3 of the Convention, the state is obliged to ensure that the person is in conditions compatible with respect for human dignity, and the mechanisms and instruments for the implementation of these requirements should not cause stress in a person, humiliate him, disturb him or suffer. It is possible to apply to the ECHR only in the event of a violation of Article 2 of the Convention and not of national legal guarantees.

\section{The protection of the right to health cannot be exercised without the right to a fair trial}

The ECHR's legal position in the case of F.E. against France is aimed at ensuring the judicial protection of human rights in the context of its inadequate medical care (De Salvia, 2004). The decision chosen to summarize the ECHR decision is significant because of the court's instruction to combine the specifics of medical relationships with the general prescriptions of the Convention for the Protection of Human Rights and Fundamental Freedoms.

Other rights that are also part of the right to health must be mentioned. In its practice, the ECHR includes in this category the right to physical and moral integrity, the right to information and confidentiality of information about one's health, the right to a favorable ecological environment. The ECHR has repeatedly emphasized the responsibility of the state and society for the organization of a medical system capable of providing everyone with the right to life and health.

As the norms of the Constitution of Ukraine have the highest legal force in the country, and the national legislation of Ukraine under the Vienna Convention on the Law of Treaties cannot contradict its international agreements, it can be concluded that financial relations in the context of medical reform should be regulated in accordance with the following principles:

- everyone's unconditional right to health;

- the State's obligation to provide medical assistance to those in need;

- financing health programs for the least protected categories of the population;

- creating conditions for the free development of healthcare facilities by the state, regardless of ownership; - free of charge medical care and medical care in cases stipulated by law. 
We will now pay attention to the implementation of these principles at the level of sectoral legislation. In line with the Healthcare Financing Reform Concept, the principle of combining different sources of funding for health care is introduced. In particular, funding for the implementation of the Concept is carried out at the expense of state and local budgets, other sources, as well as through international technical and financial assistance (Order of the Cabinet of Ministers of Ukraine On approving the Health Care Financing Reform Concept, 2016).

\section{The state does not cover all aspects of providing medical care to citizens}

From the above provision, it follows that the state does not cover all aspects of providing medical care to citizens, but resorts to limited funding, since the state budget funds are only one of the types of sources of financing. Let us find out where the public finances will be spent on medical reform. According to Article 3 of the Law of Ukraine, "On State Financial Guarantees of Medical Services to the Population in Ukraine", the state guarantees full payment according to the tariff at the expense of the State Budget of Ukraine for providing citizens with the necessary medical services and medicines provided by the program of medical guarantees (The Law of Ukraine on State Financial Guarantees of Medical Services for the Population, 2017).

As the state and municipal health care establishments operate in accordance with Article 19 of the Constitution of Ukraine, according to which they are allowed only what is explicitly provided by law, it can be concluded that the program of medical guarantees does not restrict the right to free medical care for the population, but specifies it is a right, increasing the level of legal certainty in the relationship between the patient and the healthcare facility. State funding for medical reform by subjective criterion needs to be considered in two aspects: financing of state and municipal health care institutions and similar private property institutions.

On the whole, the state develops financial policy in the direction from centralized financing of a wide network of health care institutions, to the purchase of medical services from these institutions, in order to provide medical care to the least protected categories of the population of Ukraine. According to the Healthcare Financing Reform Concept, the new principle of "money follows the patient" is proclaimed to finance health care activities. This means that health care facilities should be transformed into autonomous business entities, which will be paid for the results of their activities, which are measured by the volume and content of the care provided to patients.

In addition, given the need for the gradual introduction of new rules for the financing of health care in the transition period, over the period 2018-2019, there will be a parallel instrument for financing the primary health care unit through the medical subvention mechanism through the allocation of additional funds from the State or local budgets. By 2020, all health care institutions, regardless of the level of care and health care delivery, should move to a new funding system through contracting by an authorized entity. The autonomy of health care institutions envisaged within the framework of medical reform will result in the state actually shifting responsibility for all financial risks in the sphere of medical activity.

Repeatedly mentioned in the work of the Law of Ukraine "On State Financial Guarantees of Medical Services for the Population" in Article 8 provides for such an instrument of distribution of state financial resources between the subjects of medical care provision, as an agreement on public health services. The parties to this agreement are the authorized executive body and the medical institution, regardless of the form of ownership. The content of the agreement is that the healthcare institution provides services to the public for free according to the program of medical guarantees, and the client of medical services pays their costs at the expense of public funds, in accordance with a uniform system of tariff rates and correction coefficients.

\section{Conclusions}

Financing health care is a necessary component of the effectiveness of health care reform, as cash is the resource through which the necessary medicines and equipment can be purchased to provide medical care. That is why, in many cases, the prospect of practical implementation of medical reform prescriptions depends on the planning and coherence of the system of financing medical activities. Based on the work done, we have drawn the following conclusions:

- health care financing reform aims at improving the efficiency of budget spending and improving the conditions for the state to fulfill its constitutional obligation to a person in the protection of their health; - there is a shift of the state from centralized financing of medical activity to autonomization of medical institutions and differentiation of volumes of financial receipts, depending on the quantity of patients of the respective institution.

- the state limits its financial participation in the activities of medical institutions only by providing cash infusions within the framework of the program of medical guarantees for the population;

- since the medical reform of its implementation plan will only be completed in 2020, it is still too early to speak of its effectiveness. A prospective study will be conducted by the Institute for the Financing of Medical Assistance to the Population after its use. 


\section{References:}

Boyle, K. (2004). The right to life under the European Convention on Human Rights (Article 2). In European Convention on Human Rights: Fundamentals, Practice, Ukrainian Context. Kyiv: VIPOL. (in Ukrainian)

Convention for the Protection of Human Rights and Fundamental Freedoms (1950, November, 4). URL: http://zakon1.rada.gov.ua/laws/show/995_004

Convention on the Rights of the Child. URL: http://zakon.rada.gov.ua/laws/show/995_021

De Salvia, M. (2004). European Convention on Human Rights. Guidelines for case law relating to the European Convention for the Protection of Human Rights and Fundamental Freedoms. Case law from 1960 to 2002. St. Petersburg: Law. Press Center. (in Russian)

End of life and the European Convention on Human Rights. URL: http://www.echr.coe.int/documents/ Fs_euthanasia_eng.pdf

European Social Charter. URL: http://zakon.rada.gov.ua/laws/show/994_06

European Code of Social Security. URL: http://zakon.rada.gov.ua/laws/show/994_329 (in Ukrainian)

International Covenant on Economic, Social and Cultural Rights. URL: http://zakon.rada.gov.ua/laws/ show/995_042

Order of the Cabinet of Ministers of Ukraine On approving the Health Care Financing Reform Concept. URL: http://zakon3.rada.gov.ua/laws/show/1013-2016-p

Senyuta, I. Ya. (2015). Health and human rights: a resource guide. Lviv: Publishing House LOBF "Medicine and Law". (in Ukrainian)

The Law of Ukraine on State Financial Guarantees of Medical Services for the Population. URL: http://zakon.rada.gov.ua/ laws/show/2168-19

Universal Declaration of Human Rights. URL: http://zakon.rada.gov.ua/laws/show/995_015 